\title{
August Wilson's Presentation of Interracial Movements in 1960s
}

\author{
Yanghua $\mathrm{Li}^{1}$ \\ ${ }^{1}$ School of Foreign Languages, Leshan Normal University, Sichuan, China \\ Correspondence: Yanghua Li, School of Foreign Languages, Leshan Normal University, Sichuan, China. E-mail: \\ natalie_mint@163.com
}

Received: March 25, 2018 Accepted: May 10, 2018 Online Published: May 12, 2018

doi: 10.5539/elt.v11n6p41

URL: http://doi.org/10.5539/elt.v11n6p41

\begin{abstract}
August Wilson's Two Trains Running tells the life predicaments of the patrons at Memphis' restaurant in the 1960s. Though Wilson avoids addressing the interracial conflicts and movements on stage to eschew protesting and propaganda, they as social background could not be totally ignored in the play. The paper analyses Wilson's use of symbolic characters, off-stage space and storytelling to show how the playwright implies his assessment of the black political movements and of the political awareness of common blacks in1960s.
\end{abstract}

Keywords: August Wilson, off-stage space, storytelling, symbolic character

\section{Introduction}

August Wilson (1945-2005), African American poet and playwright, is thought to be on a par with great American dramatists such as Eugene O'Neill, Tennessee Williams and Arthur Miller. He ambitiously and successfully finished his Pittsburgh cycle (Note 1), a set of ten plays, to record the life and struggle of African American in each decade of the twentieth century.

Two Trains Running, the seventh play in the Pittsburgh cycle, revolves on the life of black Americans in the 1960s. Upon discussing 1960s in USA, it can't afford to ignore the national-wide interracial social movements for equal rights and desegregation. The decade of $1960 \mathrm{~s}$ is a period when the African Americans as a people underwent from the non-violent Civil Rights Movement to the radical, violent Black Power Movement. August Wilson, however, mentioned little about these main issues. Rather, he focused on the predicaments of patrons at Memphis's restaurant in Hill District Pittsburgh. There is no central character nor central conflict in the play. Most of the time, the patrons just sit in the restaurant, telling their past experience or complain about their current situations to each other. The political turmoil and race riots seem far away from them.

In fact, these political movements had a great influence on Wilson. He compared the Black Power Movement as a kiln and admitted that "[it] has much to do with the person I am today and the ideas and attitudes that I carry as party of my consciousness" (1996). Even if Wilson avoided mentioning the red-lettered events directly, he implied his assessment of the-blacks-fighting-for-rights movements and of the political awareness of common blacks by means of symbolic characters, off-stage space and storytelling.

\section{Hambone--Association with the Civil Rights Movement}

Wilson designed symbolic figures whose behaviors and thoughts are linked to the ideologies of these black social movements of the 1960 s.

Hambone is the one associated with the Civil Rights Movement. He is introduced as one whose "mental condition has deteriorated to such a point that he can only say two phrases, and he repeats them idiotically over and over" (Wilson, 2007). For nearly ten years, he goes to see Lutz, the white owner of a meat market, and hopes the latter to give him the ham he thinks he deserves. The only sentences he could say are "I want my ham" and "He gonna give my ham" (ibid. p. 17). Hambone's non-violent method is akin to the method used by participants in the Civil Rights Movement. As Tyndall asserts, the sentence patterns of Hambone's mantra "I want my ." and "He (the European-American man) gonna give me my " (2002) are representative of Civil

Rights ideology. His nearly ten-year struggle symbolizes the efforts of those who support and join in the Civil Rights Movement during the whole 1960s. Hambone's existence with his repetitive mantras punctuates the dialogues among other restaurant patrons, and reminds the audience of the on-going civil rights movements outside the restaurant. 
Wilson, however, doesn't just present the Civil Rights Movement. More importantly, he conveys his assessment of the movement through two versions of Hambone's story. One version is told by Holloway. In this version, Lutz promises to give Hambone a ham if he paints the fence around the meat shop. But when Hambone finishes the job, Lutz tells him to take a chicken or take nothing. Hambone refuses to accept the chicken and is driven mad. Since then he has kept waiting in front of the shop every morning and repeated the two sentences in hope that one day Lutz could give him the ham. Another version is told by Memphis. In this version, Lutz tells Hambone to paint the fences, and if he does a good job, he will have a ham; if not, he would just get a chicken. When Hambone finishes it, Lutz values Hambone's job as mediocre and gives Hambone a chicken. Hambone doesn't think so and insists on the ham. Since Lutz refuses to give him the ham, his mental condition deteriorates. In Holloway's version, Lutz is to be blamed for Hambone's deteriorating mental condition. But in Memphis' version, Hambone himself should be blamed for his madness, because he "[let] Lutz decide what to pay him for his work" (Wilson, 2007) and then "let Lutz drive him crazy" (ibid. p. 42). Like those civil-right black Americans, Hambone claims for things within the system in a non-violent way. When he started his painting work for Lutz, he acquiesced to Lutz's right to make the rules. Hambone, like those civil rights-inspired men, is asking the white Americans to give him something. Those civil rights-inspired men admit that the whites enjoy the privilege over them. They struggle for the ham, freedom or equality while not questioning the social system which is the root of their sufferings. As for the two versions of Hambone's experience, Wilson never offers a clear answer to which one is right. Rather, he makes "his attempt to force audiences as Janelle Reinelt says, to 'engage the problems' and consider the way such problems impact them as "social subjects" (Noggle, 2007). The audience will make their own judgment and the interpretation on the so-called oppression and deception of the blacks by the whites through the two version of Hambone's story.

Thought Wilson makes no comments on stories of Hambone, he implies his opinion on hambone's insistence on the ham by denying the ham to Hambone till his death. The end of the play dramatizes Hambone's futile by Memphis' mimicking the mantras "He gonna give me my ham. I want my ham." As the stage direction reads, there is pain caused by "all the cruel and cold ironies of life" (2007). In an interview, Wilson explains that Hambone could not get the ham "because he didn't take it. That's how you get your ham in American society. If you're standing around waiting for someone to give it to you and they don't give it to you" (Grant, 2006). Nearly ten-year struggle for the ham rewards Hambone nothing. It suggests the inefficiency of the Civil Rights movement in the 1960s. Knowing that action is more important than words, Wilson suggests that the high-profile slogans of Civil Rights Movement are not effective to help African Americans through Hambone and his futile struggle.

\section{Sterling--Association with the Black Power Movement}

Compared with the reference to the Civil Rights Movement, the mention of the Black Power Movement in the play is obvious and direct through the character Sterling.

Sterling's experience and behavior "echoes the similarly controversial ideology [shared by] fellow revolutionary activists of the turbulent '60s" (Shannon, 1995). When he is released from the jail, he accepts the tenets of the Black Power Movement. He is definitely one of the "Black Power niggers" (Wilson, 2007), joining in relevant activities and crying out the slogans of "black power" and "black is beautiful" on stage. Sterling hands the restaurant regulars the flyers advertising the rally to celebrate Malcolm X's birthday (Note 2). When West, Holloway and Memphis prefer to be onlookers, he participates in the rally. While other blacks submit to Albert's cutting the number, Sterling is the only one who goes to see Albert with a gun, and asks him to return his two dollars. While Hambone only asks Lutz for him ham, Sterling bursts into Lutz' shop and gets the ham. The mixture of violence and crime in the action of Sterling links him with those black power men.

Strictly speaking, the phase of Civil Rights Movement and that of the Black Power Movement do not happen one after another, but overlapped. The influence of the Civil Rights Movement could not disappear immediately when the Black Power Movement thrives. The organizations related to these two movements also rival with each other for members, donations and power. The ideologies of these two movements also compete with each other. The competitions could weaken the influence of these movements and even inflict insidious destruction on the unity within African Americans. This kind of mutual influence and competition is well shown in the scenes where Sterling teaches Hambone the black power slogans.

The boisterous teaching scenes demonstrate the mutual influence and tension between the two movements. Sterling tries to imbue Hambone with the Black Power ideologies. Hambone could temporarily repeat the words Sterling teaches him. But near the end of the teaching, Sterling suddenly calls out Hambone's mantra "I want my ham" and repeats it several times. This shows the imperceptible influence of Hambone on Sterling. Meanwhile, 
when finally Sterling shouts "Malcolm X," Hambone does not follow him. Bottoms thinks it significant that "Sterling's cry of 'Malcolm X!' is the one slogan he cites that Hambone proves unable or unwilling to mimic" (Wilson, 2007). This detail shows the tension between the pro-civil-rights blacks and the pro-black-power blacks. These two movements could influence each other, but the ideologies of non-violence and violence are incompatible.

Furthermore, the teaching scenes ridicule the hollow nature of the political rhetoric. Though Hambone would learn them word by word, he forgets them quickly and resumes his own mantras. For Hambone, "his desire for a ham as just compensation represent[s] a real, concrete cause, while the words 'Black is Beautiful' or 'United we stand' have no real, active value for him. They remain at the level of rhetoric" (Elam, 2004). Memphis rejects Sterling's idealization of black power, accusing them of getting people confuse and holding that "They don't know what they doing themselves" (Wilson, 2007). The refutation confirms that the black power slogans could not help people understand the freedom struggle movements further nor help the blacks get what they want. These cries are as inefficient as the asking-for-something strategy used by the civil rights members. Rhoda Lois Blumberg contends that "The black power leaders' rhetoric 'provided little direction for channeling the expressive energy of the people toward long-term goals" (1991). It is "vague enough to encompass a wide range of perspective" (McLemore, 1994) so that it could not reach ordinary blacks' understanding. Through this well-arranged scene, Wilson points out "the need of African Americans not simply to mouth global strategies of unity and reform but to work specifically and collectively on a local level for change" (Elam, 2004).

The increasingly factional disputes endanger the unity in either the Civil Rights groups or the Black Power groups. Wilson makes a percipient comment on the divisions within the movements, and announces that "Niggers killed Malcolm" (Note 3) (Wilson, 2007). As the death of Malcolm is concerned, Wilson's Two Trains Running is different from plays made by the 1960's black playwrights. Take Amiri Baraka for example. In The Death of Malcolm X (1966), Baraka accuses whites of conspiring to assassinate Malcolm X. The purpose of Baraka is to "prick white consciences and incite African American emotions" (Hay, 1994). One the other hand, the purpose, as for Wilson, is to prick the black consciences, to enable them to recognize themselves better as a people, and to evaluate "the choices that we as blacks in America have made" (Moyers, 2006). No matter whether the choices are correct or not, we have to face it.

Through the teaching-scene between Sterling and Hambone exhibits the tension and rivalry between the Civil Rights Movement and the Black Power Movement. He points out that the rivalry and tension could deepen the division between African Americans and damage the achievements of these freedom struggles. Besides, he warns African American against the struggle within the system and points out that it's useless to let others make the rule.

\section{Off-Stage Space and Story-Telling}

Though the thoughts and behaviors of Hambone and Sterling are linked to the ideologies of Civil Rights Movement and the Black Power Movement, the associations are obvious to tell. In addition to the symbolic characters, Wilson presents the non-violent Civil Rights Movement and the violent Black Power Movement off stage and reveals peoples' attitude towards these political movements through storytelling.

Pfister notices that "it is often, though not exclusively, the case in dramas consisting of a single locale that the spatial contrast between the stage and the off-stage is modeled to represent a central semantic opposition" (1988). Wilson puts events such as rallies, funerals, fire accidents, and interracial conflicts off stage, while on stage nothing happens except the characters tell stories. Storytelling is the oral tradition of the black culture, "essential to the form and substance of much black drama" (Pereira, 2007) Wilson's plays rely extensively on storytelling. He said once in an interview:

"So anytime you have five black characters on stage, it's very natural for them to tell stories, because the stories are the only way that cultural information, ideas and attitudes, community sanctions, ways of conduct, et cetera, are revealed." (Üsekes, 2003).

In view of the oral tradition, it seems natural that a bunch of blacks talk about what happens to them or to the community such as rallies, funerals or riots which are associated with Martin Luther King and Malcolm X.

One important issue that lasts throughout the play off stage is the funeral of Prophet Samuel. Prophet Samuel dies before the action of the play begins and his funeral is held off stage and told by the restaurant patrons. He is a prophet of the Black church in the Hill District, and leader of the First African Congregation Kingdom. During the Civil Rights Movement, "the churches were crucial in the mobilization of blacks and whites for mass meeting, demonstrations, and marches" (Hayes, 1993). Trudell contends that "the leadership of the African 
American community that was prominent before, during, and after the civil rights movement was so closely associated with religion and spirituality" (2007). Take Martin Luther King Jr. (leader of the Southern Christian Leadership Conference), and Elijah Muhammad (leader of the Nation of Islam) for example. Similarly, Prophet Samuel "orchestrates his own liberation by linking his fate with that of Mellon" (Note 4) (Elam, 2004). In other words, his power and success in the district is granted by the white authority. The cooperation with white liberals and acceptation of their donations is a common practice in the Civil Rights Movement. In this light, Prophet Samuel's role as a reverend is symbolic and directly associated with leaders of the Civil Rights Movement.

When the funeral of Prophet Samuel comes, what the blacks care about are money and material gains. They line up to see the prophet's mortal remains, not because they want to pay their homage to him, but because it's said that rubbing Prophet Samuel's head would bring one good luck. One of the Prophet's mistresses even wants to charge the people for seeing and rubbing his head. The patrons in the restaurant "remark not on the reverence and spirituality of the proceedings but compare the size, spectacle and chaos of the funeral rites for a notorious gambler and hustler, Patchneck Red" (ibid, 194). The funeral seems like a site of pomp and revel. Through the blacks' behaviors and attitudes to Prophet Samuel's funeral, Wilson demonstrates the debased collective mentality and insufficient political awareness of African Americans as a people.

Off stage, a rally to celebrate the birthday of Malcolm X is also under way though three fourths of the play, ending with a fire in the black community. The fire and riot is similar to the three-day looting and violence in April 1968 following the murder of Marin Luther King, Jr.. Most importantly, Wilson questions the motivations of blacks in these social issues through Wolf and Sterling.

Though Sterling calls out the black power slogans, he would possibly not understand the meaning implied in the slogans. He tells Memphis that when teaching Hambone the slogans, "[he] was just having some fun" (Wilson, 2007). He attends the black power rally also for fun, giving a big smile when the police take his picture, just as Elam contends "while he [Sterling] attends Malcolm X rallies, his politics have not evolved beyond rhetoric into action" (2004). When Sterling tells others what happens in the rally, his words sound childish. As for Wolf, he thinks the rally is "real nice" (Wilson, 2007) because everybody is there, and no fight or something else happens. The whole night, he stands there watching. He is excited to see the fire and "ten, eleven fire trucks and near about a hundred police" (ibid. 94) around there. Both of Sterling and Wolf focus on the spectacle and chaos of the rally as other people do in case of Prophet Samuel's funeral. They mention nothing about the purpose of the rally, or maybe they never know about it. Wilson criticizes this kind of black Americans through Memphis:

All them niggers wanna do is have a rally. Soon as they finish with one rally they start planning for the next. They forget about what goes in between. You rally to spur you into action. When it comes time for action these niggers sit down and scratch their heads. (ibid. 77)

Though the blacks talk about freedom, justice, and equality, they "don't know what it mean" (ibid. 40). The Civil Rights Movement and the Black Power Movement, as Wilson held in an interview, "didn't reach the average person who was concerned with just simply living" (Pettengill, 1994). Through character's storytelling and the use of off-stage space, Wilson reveals the lack of action and the insufficient political awareness of the common African American.

\section{Conclusion}

Though Wilson avoids addressing the interracial conflicts and movements on stage, they as social background could not be totally ignored. To eschew protesting and propaganda, he mainly puts these turbulent issues off stage, and designs dramatic figures that embody the 1960's freedom struggles along with direct reference to the movements in the conversation. Meanwhile, though presenting various opinions on inter-racial conflicts and struggles through dialogues, Wilson forces the audiences to listen to the dialogues, thinking and making judges on the choices African Americans made in the 1960's. In these and many other ways, Wilson tentatively and yet provocatively provides his percipient view of the interracial struggles as well as the political awareness of common African Americans of that time.

\section{Acknowledgement}

This work is sponsored by "Research Center of Foreign languages and Cultures in Sichuan" (Grant SCWY15-13). 


\section{References}

Blumberg, R. L. (1991). Civil rights, the 1960's freedom struggle. rev. ed. Boston: Twayne Publishers.

Bottoms, S. (2007). Two Trains Running: Blood on the tracks. In C. Bigsby (Ed.), The Cambridge Companion to August Wilson (pp. 145-157). New York: Cambridge University Press. https://doi.org/10.1017/CCOL0521866065.011

Elam, H. J. Jr. (2004). The past as present in the drama of August Wilson. Ann Arbor: University of Michigan Press. https://doi.org/10.3998/mpub.17666

Grant, N. L. (2006). Men, women, and culture: A conversation with August Wilson. In J. R. Bryer, \& M. C. Hartig (Eds.), Conversations with August Wilson (pp. 172-187). Jackson: University Press of Mississippi. https://doi.org/10.1086/500603

Hay, S. A. (1994). African American theatre: A historical and critical analysis. New York: Cambridge University Press. https://doi.org/10.1017/CBO9780511570438

Hayes, C. A. (1993). A critical and historical analysis of five major plays by August Wilson (Doctoral dissertation, Southern Illinois University at Carbondale).

McLemore, S. D. (1994). Racial and ethnic relations in America. (4th ed). Boston: Allyn and Bacon.

Moyers, B. (2006). August Wilson: Playwright. In J. R. Bryer, \& M. C. Hartig (Eds.), Conversations with August Wilson (pp. 61-80). Jackson: University Press of Mississippi.

Noggle, R. (2007). From the Individual to the Collective: Community in August Wilson and Tony Kushner. (Doctoral dissertation, University of Kansas).

Pereira, K. (2007). Music and mythology in August Wilson's plays. In C. Bigsby (Ed.), The cambridge companion to August Wilson (pp. 65-74). New York: Cambridge University Press. https://doi.org/10.1017/CCOL0521866065.004

Pettengill, R. (1994). The historical perspective: An interview with August Wilson. In M. Elkins (Ed.), August Wilson: A Casebook (pp. 207-226). New York: Garland.

Pfister, M. (1988). The theory and analysis of drama.John Halliday (Trans). Cambridge: Cambridge University Press. https://doi.org/10.1017/CBO9780511553998

Shannon, S. G. (1995). The dramatic vision of August Wilson. Washington: Howard UP.

Snodgrass, M. E. (2004). August Wilson: A literary companion. Jefferson, N.C.: McFarland \& Co.

Trudell, S. (2007). Critical essay on Two Trains Running. In D. Galens et al. (Eds.), Drama for students: Presenting analysis, context and criticism on commonly studies dramas (Vol. 24, pp. 272-275). Detroit, MI: Gale .

Tyndall, C. P. (2002). August Wilson's play cycle: A healing black rage for contemporary African-Americans (Doctoral dissertation, The University of Texas at Austin).

Üsekes, Ç. (2003). "We're the leftovers": Whiteness as economic power and exploitation in August Wilson's twentieth-century cycle of plays. African American Review, 37(1), 115-125. https://doi.org/10.2307/1512364

Wilson, A. (1996). The ground on which I stand. Retrieved from http://www.nathanielturner.com/groundonwhichistand.htm.

Wilson, A. (2007). August Wilson century cycle: Two trains running. New York: Theatre Communications Group.

\section{Notes}

Note 1. The ten plays are Gem of the Ocean (2003) about 1900s, Joe Turner's Come and Gone (1988) about 1910s, Ma Rainey's Black Bottom (1984) about 1920s, The Piano Lesson (1990) about 1930s, Seven Guitars (1995) about 1940s, Fences (1987) about 1950s, Two Trains Running (1990) about 1960s, Jitney (1982) about 1970s, King Hedley II (1999) about 1980s, and Radio Golf (2005) about 1990s.

Note 2. Malcolm X was first a member of the Nation of Islam and had played a leading role in this group since 1952. 
Note 3. As the disagreements in the political issues such as the assassination of President Kennedy between Malcolm X and other leaders in this group increased, Malcolm left the organization in 1964 and founded Muslim Mosque, Inc. In 1965, he was assassinated by three members of the Nation of Islam during a public address.

Note 4. Mellon is referred to Andrew William Mellon (1855-1937). He is the owner of Gulf Oil. Also, he set up Union Trust and Union Savings Bank of Pittsburgh as well as Alcoa and Union Steel. He is "a symbol of the white world of money, materialism, and entrepreneurial power" (Snodgrass 141).

\section{Copyrights}

Copyright for this article is retained by the author(s), with first publication rights granted to the journal.

This is an open-access article distributed under the terms and conditions of the Creative Commons Attribution license (http://creativecommons.org/licenses/by/4.0/). 